\title{
The Influence of Latinisms on the Quality of the Judgments of Polish Courts
}

\author{
Joanna Kowalczyk ${ }^{1}[$ ]
}

Accepted: 25 May 2021 / Published online: 12 June 2021

(c) The Author(s) 2021, corrected publication 2021

\begin{abstract}
This article addresses the issue of linguistic phenomena which, as a legacy of the centuries-old tradition of the Roman Empire, are rooted in Polish jurisdictional texts. The study focused on foreign-language expressions and short texts in Latin, used in judicial decisions. The aim of the study was to determine the function of Latinisms as foreign-language expressions in judicial decisions and how their use influences the communicativeness and persuasiveness of argumentation. During the analysis, it was noticed that Latinisms in jurisdictional texts are used on four levels, including: legal maxims, terminology equivalence, linguistic ornaments and the description of taboo phenomena. On the basis of the identified categories, efforts were made to determine the extent to which Latin strengthens or weakens the power of persuasion of judicial decisions.
\end{abstract}

Keywords Latinisms · Legal discourse · Court argumentation · Quality of argumentation

\section{Introduction}

The political and legal systems of the modern world were built on the foundations of the civilizational achievements of ancient Greece and ancient Rome. Roman law is present in today's legal systems, regardless of their constitutional basis or lawmaking forms. It is a component of both continental and Anglo-Saxon law [24: 6] . Ancient influences also left their mark linguistically. One of the linguistic phenomena rooted in Polish legal terminology are Latinisms - the heritage of centuries-old Roman tradition [25: 71]. In the legal world, they are used both in their original and translated forms. They play a special role regarding terminology and the political system (legal principles). They are widely used in doctrinal disputes, in courtrooms and in argumentation concerning judicial decisions.

Joanna Kowalczyk

joanna.kowalczyk@ujk.edu.pl

1 Jan Kochanowski University in Kielce, Żeromskiego 5, 25-369 Kielce, Poland 
The present article concentrates on judicial argumentation in which Latinisms are used as functional elements of judicial decisions. The study covered parts of judicial arguments that used Latin expressions, terms and phrases in their original form (original Latin spelling). The aim of the analysis was to determine the function of Latinisms as foreign language expressions in judicial decisions and how the use of Latinisms in their original form influences the communicativeness and persuasiveness of argumentation, and thus-the quality of the reasoning behind the issued judicial decision. The study covered decisions taken by courts in civil and criminal cases. The sample size was 300 sentences. All decisions were obtained from the Portal of the Judgments of Polish Courts [27] created as part of the activities of the Polish Ministry of Justice. It is an open access platform in which the decisions of courts from all over the country are posted in an electronic form. The main research material consisted of fragments of the analyzed judgments containing Latin components. Either entire sentences or their separate parts were excerpted. Collecting entire sentences in which Latinisms appeared was necessary in the case where the context defined the function of the foreign-language element in the text. Selecting shorter fragments became sufficient if the definition of the role of Latinism was clear and did not require taking into account the linguistic environment in order to accurately establish its essence.

The problem posed required the use of a complex methodological apparatus. Firstly, it was recognised that the judgment as a socially significant text should be considered under the category of the performative speech acts [1: 543-729]. Undoubtedly, it is not only an intentional act, but above all a perlocutionary text that has a real impact on the behaviour and feelings of the addressees, readers, people interested in the issues raised in the judgment, lawyers or law students. Secondly, the elaboration likelihood model of Richard Petty and John Cacioppo $[15,16]$ was used. It proved to be extremely helpful in assessing the recipient's level of motivation necessary to decode the message. Based on such assumptions, an attempt was made to analyze the collected material in terms of its real functionality. In order to do so, first of all the examples gathered were looked at taking into account the role they played a given judgment. Then they were grouped according to the categories defined during the research. Each of the observed classes of Latinisms was characterized in relation to its communicative utility. The description also takes into account the real and potential impact of the use of Latinisms on the quality of the court's judgements.

\section{Stylisation in the Motivation of Judicial Decisions}

From the perspective of the pragmatics of communication, the judicial decision is primarily a type of impressionistic expression. It is a performative message which may regulate the extra-linguistic reality through argumentative strategies [7: 136]. In this case, it is not only logical coherence but also the surface form of the message that constitute a particularly important element shaping the reflexive relationship between the argument and the recipient of the argument. Using the Quintilian nomenclature, inventio and dispositio have the quality imposed by elocution [cf. 9]. 
Formulating court argumentation is a kind of ritual, developed on the basis of conventional actions (formal adequacy), formal style (e.g. on behalf of the Republic of Poland) and the binding character of the decisions contained therein (e.g. the court finds the accused guilty and imposes a penalty of imprisonment).

The present article focuses on the stylistic component of the argument. First and foremost, it should be emphasised that the surface layer of the text constitutes one of persuasive elements that not only directs the recipients' way of thinking but also arouses or calms their emotions [14: 34]. The choice of language tools to support premises and conclusions is as important as the rationale itself. Judges use a variety of linguistic instruments to express and substantiate a judgment. Judgments are eclectic texts full of specialised terminology, legal jargon, quotations or idiolectal expressions including phrases and terms in Latin [7]. On the basis of the conducted analysis, it was observed that Latinisms are used in sentences in order to play on of the four functions: maxims, equivalents of native terminology, linguistic ornaments and a way of describing taboos.

\section{Legal Maxims}

The law maxim is often used in justifications of judgments issued by Polish courts. This is due to several factors. Firstly, polish legal language is largely based on ideas developed in the Roman Empire [cf. 23-25]. Judges, prosecutors and lawyers use this set of instruments, seeing in it ready-made axiological models. Maxims enrich argumentation with instructive thoughts and morals rooted in the tradition of the democratic world. What is a maxim if not a moral, ready-made instruction? This undoubtedly constitutes its argumentative force. It adds a significant and universal character to a statement. In addition, the fact that a maxim is given in Latin means that the judge, who presents arguments by means of such sentences, appears to be well-read and eloquent and to know a given case thoroughly. To this day, Latin remains in the minds of Poles the language of sages, educated people and poets, which is why sentences in Latin evoke a kind of respect towards those who use such a maxim. In a way, people admire Latin, associate it with an unattainable ideal and recognise it as a mystical, beautiful language. For this reason alone, it should be recognised that the combination of a sentence with the Latin form of its expression is a way to provide the argument with a certain style, giving it an attribute of importance. Reaching for a maxim also builds the image of the court as a subject that, when issuing a ruling, reaches to primordial sources and searches not only for literal provisions of the law, but also draws from universals which are not relativised by the requirements of a specific legal system.

However, there remains one contentious issue. Since it is recognised that the law maxim is a moral instruction and a warning, the impact of such texts is inextricably linked with the comprehensibility of the content. The addressees should easily decode the meaning of the manifested moral. The content is the essence of the sentence, therefore unless the content is understood the sentence remains an empty part of the text that may be omitted by the reader or merely noticed, but not decoded. Therefore, the use of maxims written only in Latin in judicial 
argumentation carries a real risk of depriving these maxims of the potential to evoke reflections in the reader, which are a way to convince the addressees of the validity of a court decision. It should not be expected that every person reading the justification will strive to establish the meanings of its Latin parts, especially when there are plenty of them, cf.

- It is true that the principle lex retro non agit can be derived from the Constitution, but only to the extent that it coincides with the principle of nullum crimen sine lege. To put it another way, the nullum crimen sine lege principle is a certain aspect of the lex retro non agit principle ( $\mathrm{Pl}$. z Konstytucji wyprowadzić można wprawdzie zasadę lex retro non agit, ale tylko w takim zakresie, w którym pokrywa się ona $\mathrm{z}$ zasadą nullum crimen sine lege. Ujmując to inaczej, zasada nullum crimen sine lege stanowi pewien aspekt zasady lex retro non agit) [28].

Of course, it can be expected that persons directly involved in the trial (e.g. defendants or victims) will take steps to understand unclear messages. At this point, however, it is worth recalling the theory of Richard Petty and John Cacioppo $[15,16]$, i.e. that information overload and a large number of messages that are difficult to decode mean that only those with strong cognitive motivation will make the effort to understand them. According to the postulates of the concept of social attitudes $[19,20]$, a person is primarily motivated to work out ideas, messages, events, etc., which cause strong ego-involvements. In turn, the level of ego-involvement is directly proportional to the importance of the specific issue for the recipient.

The review of motivations of court decisions has led to the conclusion that some judges see the need to use Latin sentences within the Polish-language frames. For this reason, motivations in which a law maxim appears only in Latin (e.g.: A temporal conflict between acts in Art.4 $\$ 1$ of the Penal Code was resolved in accordance with the principles:lex severior retro non agit, lex mitior retro agit ( $\mathrm{Pl}$. Kolizję czasowa pomiędzy ustawami $w$ art. 4 \$ 1 k.k. rozwiazano zgodnie z zasadami:lex severior retro non agit,lex mitior retro agit) [28]; This also raises doubts as to the legitimacy of taking into account such claims and the clash of this practice with the fundamental principle of lex retro non agit (Pl. To także budzi watpliwości co do zasadności uwzględniania takich roszczeń i sprzeczności tej praktyki z fundamentalna zasada lex retro non agit) [29]) are only one of the tendencies. Simultaneously, there is a tendency to use law maxims in two language versions at the same time i.e. in Latin and its Polish translation, see:

- When assessing the defendant's attitude, in the present case, one should refer to the basic principle of the law of obligations, i.e. pacta sunt servanda (agreements must be kept) (Pl. Oceniając postawę pozwanego, w niniejszej sprawie należy przywołać podstawową zasadę prawa zobowiązań tj. pacta sunt servanta (umów należy dotrzymywać)) [30];

- Known for over two thousand years and derived from the Roman law, the principle ignorantia iuris nocet (ignorance of the law is harmful), in this case was fully implemented (Pl. Znana od ponad dwóch tysięcy lat, wywodząca się z prawa 
rzymskiego, zasada ignorantia iuris nocet (nieznajomość prawa szkodzi), w tym przypadku znalazła swoje pełne urzeczywistnienie) [31].

The second way of introducing legal principles into court decisions and judgements seems to be a socially valuable solution. From a utilitarian point of view, it is much more desirable, as it reduces the risk of misunderstanding the content, and thus strengthens the persuasive function of the sentence. It should be noted that the people to whom the sentence is addressed are very rarely lawyers or people who know Latin, therefore, in order for the maxim to strengthen the argument, it is worth quoting its equivalent in the language of the original. This solution is also supported by the fact that the Polish-language equivalents of Latin maxims have an equally significant form and do not lose their dignity. On the contrary-they have the power to reach every reader because they are understandable to everyone. Their style, overtone and rhythm are also transposed in such a way as to maintain the convention of a content-rich, but compact, short, instructive, solemn motto, see:

- Latin: Dura lex, sed lex; Polish: Twarde prawo, ale prawo (The law is harsh, but it is the law);

- Latin: Lex retro non agit; Polish: Prawo nie działa wstecz (A law does not apply retroactively);

- Latin: Ignorantia iuris nocet; Polish: Nieznajomość prawa szkodzi (Not knowing the law is harmful).

There is one conclusion that comes to mind-a law maxim has enormous persuasive and cognitive potential. One only needs to properly reveal this potential and skilfully use it. In the case of arguments that motivate a specific judgment, law maxims may prove extremely useful. This is because the motivations of court decisions are often long texts, fraught with legal jargon and a large number of cited provisions. Arguments supported by sentences appropriately selected for a given situation may gain transparency. Law maxims can constitute a specific punch line for substantive considerations. With the help of one abstract maxim, an infinite number of real events can be regulated. Thanks to their conciseness, uniqueness and universality, they provide a chance for a clear and simple expression of a judgment. They turn dry facts into an emotional, even educational, reflection. They extract the spirit of the law from the law understood literally. This, in turn, may affect whether the judgment issued will be only accepted/respected, or also understood and accepted by the addressees as fair, proper and just [11: 494]. The recipient's acceptance is the ultimate measure of the success or failure of an argument [15, 26: 32]. Hence, in order for the aphorisms to function, they must be received by the addressee. The use of a law maxim merely quoted in Latin is an argument for exclusion as it becomes understandable only to an elite group of lawyers. It limits the chances of accepting the message even by those who know at least the most popular law maxims but in their native language (e.g. Polish: Nie ma przestęstwa bez ustawy [No crime without law] vs Latin: Nullum crimen sine lege; Polish: Nikt nie może być sędzia we własnej sprawie. [No-one is a judge in his own cause] vs Latin: Nemo iudex in causa sua. In this way, the argument with the potential of persuasion is reduced to the "Electra 
paradox" [cf. 18: 86-88], as it becomes invisible, obscured by the "cover of a foreign language".

\section{Latin Substitutes for Domestic Terminology and Polish-Latin Hybrids}

The use of Latinisms as equivalents of native legal terminology is a common phenomenon in judicial argumentation, cf.: corpus delicti instead of narzedzie przestęstwa (Eng.: body of the crime); culpa instead of wina umyślna (Eng.: deliberate negligence); dolus instead of wina nieumyślna (Eng.: fraud). The motivations of court judgments contain not only full substitutes for Polish terms but also partial replacements, which means that one part of the compound term is rendered in the native language and another in Latin, cf.: sqd a quo (court a quo) instead of court of the first instance; sqd meriti (court meriti) instead of the court of second instance; warunek sine qua non (a sine qua non condition) instead of warunek konieczny (a necessary condition).

It should be noted that Polish legal language has an appropriate nomenclature and there are no conceptual or terminology gaps to fill where it might be necessary to use nomenclature instruments derived from other languages. However, since the judgments include Latin terms instead of Polish ones, a question should be asked: how can such actions affect the quality of court argumentation?

Assuming that the purpose of court argumentation is to honestly convince the addressees of the validity of the judgment, in order to comply with this principle, when preparing the argumentation it should be ensured that the text is accessible [22] or at least allows for its decoding with the use of standard tools as much as is possible, i.e. acts. From a pragmatic and, above all, utilitarian point of view, attempts to replace Polish terms used in legal acts with Latin terms, absent in Polish legislative documents, have no substantive justification. Since the judgment and its validity are intended for a Polish-speaking participant in the trial, the entire text should be written in Polish.

It is worth emphasising that in legal and judicial discourse the term is not only a name for a specific concept but a determinant of the qualification of an act and the basis for granting or revoking a specific status to or from a person, thing or event. Legal terminology is the proper terminology by which subjective and objective relations are organised. Therefore, a legal term is not only a name, but a tool that really shapes formal and actual reality [6: 67-71]. It means that the use of a specific term causes a specific object to acquire certain features (e.g. becomes someone's property); a specific entity acquires a certain status (e.g. the injured person, the suspect, the incapacitated person, etc.) and therefore obtains certain rights or is deprived of them; a specific act is classified as permitted or unlawful and therefore has certain consequences. The use of Latin equivalents carries a risk that the person reading the judgment may incorrectly translate the Latin term into Polish and, while looking for a definition of an incorrectly translated term, may misinterpret the words of the court. For this reason, the use of Latin equivalents of legal terms in judicial argumentation may significantly hinder or, in extreme cases, make it impossible to 
decode the meaning of the arguments cited. This is especially important when there are only small differences between the terms which makes it very easy to make a mistake.

A qualitative judicial argument is a statement that can be responded to, questioned, objected to, challenged or agreed with [21]. Its transparency, also in terms of form, must be an inseparable element of such an argument. Thus, the use of foreign language terms decreases the quality of judicial argumentation and makes it an unequal struggle between professionally prepared lawyers and a frustrated addressee. An argument which is deliberately difficult to interpret, fails to actually convince the addressee to accept the court judgement or results in ignoring the cognitive abilities of the addressee is, as a rule, inaccessible and should be regarded as a manifestation of force. Both the first and the second options can be described as an aberration in the persuasion process, as they violate the fundamental right to protect the interests of the parties [cf. 2]. This violation affects all participants of the court trial since the scope of understandable messages may significantly affect the scope of possible appeals against the judgment. Even unconsciously building an argument in such a way that it becomes a barrier, instead of a point of reference, decreases the persuasive quality of the judgment and at the same time undermines citizens' trust in the institution of the court. As the court has all the powers and political support, as well as subordinate services at its disposal, it should not be additionally supported by hermetic professional jargon, the excessive exposure of which reduces it to a play with language.

The argument of the court should be an explicit statement rather than a puzzle. Decoding it should not require special skills that are unrelated to substantive legal issues. Convincing the addressees of the validity of the court's rationale is inherently rational persuasion, understood as fair practice aimed at eliminating doubts and not at discouraging the addressee from entering into negotiations only because of linguistic complexities. These may deprive them of the instruments of reaction that could be used if the combination of Polish and Latin words did not prevent them from decoding the content. It is worth noting that a legal term is the basic tool for action in court cases. By cloaking it, presenting it in a veiled form by using Latinisms, participants in the trial are deprived of the right to understand the judgment.

It must be remembered that knowledge about the determinants of decisions or actions taken is a necessary element of accepting an argument as motivated by objective, substantive reasons [22]. Such reasons should be the foundation of the motivation of the judgment. Moving away from argumentation based on a clearly communicated message to the argumentation that is complex in terms of form and therefore effectively deterring counter-argumentation means in fact moving away from the strength of the argument towards an argument of strength. This kind of interaction becomes a violent coercion, which in some cases can be qualified as manipulation. It can be concluded that the court's argumentation by using Latin terms instead of Polish ones is an unfair practice. It introduces terminological chaos, increases the risk of misinterpreting the classification of an act, etc. One more important aspect should be noted: if it is assumed that an argument is a manifesto that is supposed to confirm the thesis, then as a rule the argument refers to certain facts, circumstances, and context [21]. So if this fact is pronounced in another language, and especially in a dead 
language such as Latin, then the adversary is first referred to linguistic sourcesdictionaries of foreign terms. Failure to make the court's decision understandable is denial of a fair trial. It is difficult to burden the participants of the proceedings with first translating Latin terms into Polish in order to be able to interpret the grounds of the judgment. Thus, persuasion using Latin terms becomes quasi-persuasion and as such should be considered as defective and inherently invalid. A judgment based on an argument formulated in this way should be reviewed and corrected. In turn, the time to raise a possible objection should be counted only from the moment when the justification is corrected.

The judiciary has a social task to fulfill. There is no place for linguistic ruses here and the use of foreign-language terms in the court text can be considered such a ruse. The intention of the sender is irrelevant. All participants of the trial should be guaranteed a fair trial and the reliable argumentation of the judgment is an inseparable element. One of the elements of such reliability is the desire to formulate judicial argumentation in a way that, under optimal conditions, does not raise any doubts and allows for a response [21, 22]. Even if a specific legal term, a specific name, a specific classification of an act, a specific status of a thing or a person may be difficult to interpret, finding their definitions in Polish will be much easier than finding them in Latin.

\section{Latin Ornaments}

Judicial arguments are also rich in Latinisms that function as stylistic ornaments. For many citizens, Latin has something of an esoteric and metaphysical character and that is why it works well as an ornament. In an unexplicit way, it can add some exotic features to a text. The spectrum of Latinisms used for this purpose is broad, starting with replacing single words/compounds with the Latin equivalent (e.g. explicite instead of "jasno", "wyraźnie" ["clearly"]; meritum instead of "sedno", "istota" ["essence"]; stricte instead of "doktadnie", "ściśle" [ "exactly", "strictly"]), through entire phrases (e.g. in statu nascendi instead of "na etapie powstawania" ["at the stage of formation"]; in flagranti instead of "na goracym uczynku" ["redhanded"]), to elements of artistic discourse (e.g. deus ex machina meaning "nagle", "nieoczekiwanie" ["suddenly", "unexpectedly"]).

When discussing the group of Latinisms appearing in the texts of judgments as linguistic ornaments, it is worth noting that domesticated Latinisms constitute a relatively small group. By "domestication" I mean those units of the Latin language that have been adopted into the Polish language and are now a permanent part of the native language, and thus - natural and understandable to Polish speakers. These are words/expressions such as: sensu stricto, meritum, de facto, status quo. The use of this kind of Latinisms is entirely justified and has at least a neutral impact on the quality of the argument, as it does not distort the message. At the same time, it gives the argument a somewhat erudite character, embeds the argument in the legal code, while at the same time not confining it to an elite framework but instead allowing ordinary language users to use it. 
The second category of Latinism-ornaments which is used in motivations of court judgments is characterised by a high degree of difficulty. These are "elite" Latinisms, used by specialised professional groups (e.g. a priori instead of "odgórnie" ["top down"; a posteriori instead of "z doświadczenia" ["from experience"]; ex tunc instead of "od wtedy" ["from then"]; ex nunc instead of "od teraz" ["from now"]). Even the indicated examples show how the simplest text can be complicated by unskilfully styling it. Introducing too elaborate hermetic ornaments to the motivation of the court judgement seems to be a procedure that manifests the sender's linguistic creativity.

It is worth asking a question here: where does far-reaching text ornamentation come from in judicial argumentation? The origin of this phenomenon is close to bilingualism or diglossia. In both cases, the language user is fluent in two codes or two registers (high and low) at the same time, and is therefore able to move from one code/style to another without any problems [cf.: 3, 10]. A similar situation is observed in the texts of judicial motivations. The text written in a general style is interwoven with elements of a sublime style, but also with professional jargon, legal jargon or loanwords. Therefore, there are linguistic shifts (Polish-Latin) and stylistic shifts (informal/general style-formal style-professional style). One of the notable determinants of such an eclectic shaping of argumentation is the fact that its source may not be a well-thought-out choice of language tools to build a message but the phenomenon of code-switching, i.e. switching between codes, because these codes (or their specific collections) are treated as a unit by the sender [cf.: 12, 13]. During their professional education, lawyers are subject to the same interiorisation processes as each member of a specific language community. Acquiring specific words, phrases and whole texts is part of this sociolinguistic process [4: 96-103]. Due to the permanent incorporation of Latinisms into legal speech, they become familiar and natural linguistic signs for people with legal education and therefore used in the same way as signs from the native language and incorporated into legal statements without reflection. Using Kant's concept of als ob [5], Latinisms in the legal world can be called "as if they are" a native component of their language, because this is how they are used by lawyers in their communication.

Regarding the quality of court argumentation, ornaments that reduce the intelligibility of a court text in favour of an excessively flowery style are not desirable elements. According to "Okham's razor" [cf. 17], which is a classic principle of text and economy of thinking, redundant elements should be eliminated from argumentation. The court's decision is not the right place to display even the most interesting idiolect or sociolect. In a situation where an ornament causes even the simplest sentence and the simplest message to become a communication barrier, we are dealing with a classic triumph of form over content. By focusing on understandability vs. elaborateness of the text, the decision of the court is certainly a document in which the accessibility of argumentation is to be the most effective tool of persuasion. On the other hand, excessive use of Latinisms playing a stylistic function may be considered an argumentative aberration. 


\section{The Use of Latin to Describe Taboos}

Latin expressions in the texts of court judgments are also used to describe phenomena considered inelegant, embarrassing (e.g. related to improper personal hygiene: fetor ex ore [an unpleasant smell from the mouth]) or which can be attributed to taboo properties. A clear example is the description of sex crimes. The sexual sphere, regarded as an exceptionally private, intimate and often embarrassing sphere of human life, is a delicate matter. Talking about sexuality, especially in the context of criminal activities, may, for cultural reasons, raise numerous doubts as to how such events should be described. In order for judicial arguments to form a professional whole, the facts must be described in detail and reliably. It is largely up to their presentation whether the arguments cited by the court are convincing and not raise any doubts. Describing the sexual act is therefore often necessary for the argument to gain the value of persuasion. So even a shameful, painful event for the victim must be described in detail. Therefore the question arises: is it possible to describe, for example, a rape scene, indicate specific facts that are the basis of the argument and at the same time not to violate cultural norms and ensure the victim's comfort?

The court is faced with a difficult task of selecting linguistic means in order to present a detailed picture of the course of a sexual offense, such as harassment, pedophilia, zoophilia or rape, in the argumentation of the judgment. One must choose between accurate illustration of the facts that are the basis for the argument and cultural aspects through which the selection of specific language means is made. Evoking the course of sex crimes using only the native language makes the argument a purely naturalistic image (cf.: he put his penis into the victim's mouth by force (Pl. sita wktadat penisa do ust pokrzywdzonej) [33]; he put his penis into the vagina and had an intercourse (Pl. wprowadzit swojego cztonka do pochwy $i$ odbyt stosunek) [34]).

Undoubtedly, it stimulates the imagination of the reader who receives almost a "photographic" narrative. It is impossible for them not to imagine the scenes being read. Acts of violating sexual freedom described in this way may cause embarrassment, a sense of shame, terror or indignation. Breaking the taboo is inseparable from the sense of vulgarity [8], which is why judges, when describing such facts, sometimes resort to euphemisms, use general narrative, and when it is necessary to describe an event in detail, they resort to Latinisms to at least partially soften the message (cf. in particular, the element of "sexual intercourse" does not have to be immisio penis (Pl. W szczególności elementem "obcowania ptciowego" nie musi być immisio penis) [32]—immisio penis instead of putting a member into the genital organs (vagina) or their substitutes (anus, mouth).

Naming the types of sex or sexual deviations in the native language constitutes a taboo [8], and for this reason sometimes an avoidance argument or euphemism are used. It is realized in the use of Latinisms as a way to soften the emphatic nature of the statement, flatten emotions associated with it, and dismiss impropriety. In order to avoid the difficult topic of sexuality, judges sometimes use Latinisms, which are included in arguments as "escape from" and "escape to". This 
means that in some respects this argumentative procedure can be compared to smoothing the dissonance between the cognitive aspect and the aesthetic aspect. In this case, "escape from" is based on the avoidance of terminology which, for cultural reasons, can be controversial even when used in accordance with the standards of biological and medical sciences. "Escape to" is an attempt to use "safe" statements. It is the formulation of a conservative argument that appears non-controversial. It should be noted, however, that replacing the native sexual terminology with the Latin terminology affects the strength of the message, therefore judges very cautiously use Latin equivalents in this area. This seems to be the right way, because describing sexual crimes in a foreign language carries the risk that the harm that has been done to the victim will be diminished through the foreignization of its description, becoming less blunt, less painful, and therefore less true.

\section{Conclusions}

A review of the judgments in terms of their borrowings revealed that Latin in court texts is a readily used language code. On the basis of the Latin parts of texts excerpted from the motivations to the judgments, it was established that the courts introduce Latinisms into arguments in four main functions.

Firstly, the courts eagerly use a rich law maxims which, thanks to their brevity and universality, have the potential to transpose unemotional judgment into an educational instruction. However, in order for a maxim to perform its function, it must be understandable to the recipient. For this reason, it was noted that the use of a paraphrase quoted only in Latin risks limiting its impact to an elite group of lawyers, and thus will be of little importance for strengthening the quality of argumentation.

Secondly, judicial argumentation is fraught with Latin equivalents of native terms. As noted, this practice unnecessarily complicates the form of the message. From a pragmatic and utilitarian points of view, there is no substantive justification for replacing Polish terms with Latin terms, which are absent in Polish legislative documents.

Thirdly, there is a wide range of Latinisms-ornaments in jurisdictional argumentation. Some of them are assimilated Latinisms, i.e. also used in general Polish, and some are 'elite' Latinisms, characterized by a high degree of difficulty and used by specialized professional groups. On the basis of pragmatic reflection, it was concluded that ornaments that reduce the intelligibility of the court text in favor of an excessively flowery style are not desirable elements.

Fourthly, Latin expressions appear in judgments as a way of describing phenomena considered inelegant, embarrassing or taboo. Contrary to the previous groups of Latinisms, judges very cautiously use Latin terms in this area and in most cases Latinisms complement the Polish description.

The analysis of the use of Latin in court judgments gave an overview of the strengths and weaknesses of judicial argumentation. The reflections on the functioning of Latinisms in judicial argumentation presented in the article provide a basis for the conclusion that the strength of the text lies in its ability to reach the wide 
audience. Otherwise, it is not the content but the authority of the judgment or the fear of judgment that are the weapons of influence. Latinisms can become a reinforcement of the impact of argumentation if they are used skillfully and their use in the text is preceded by deep reflection. Ordinary language users cannot be expected to have the knowledge of Latin, and it should be noted that the main addressees of judgments are not professionals (lawyers), but unprofessional participants in a court trial. If the linguistic form makes it impossible to understand the text, it should be modified or supplemented to reach the balance between the complexity of the argument and the intellectual effort required to understand the content.

Open Access This article is licensed under a Creative Commons Attribution 4.0 International License, which permits use, sharing, adaptation, distribution and reproduction in any medium or format, as long as you give appropriate credit to the original author(s) and the source, provide a link to the Creative Commons licence, and indicate if changes were made. The images or other third party material in this article are included in the article's Creative Commons licence, unless indicated otherwise in a credit line to the material. If material is not included in the article's Creative Commons licence and your intended use is not permitted by statutory regulation or exceeds the permitted use, you will need to obtain permission directly from the copyright holder. To view a copy of this licence, visit http://creativecommons.org/licen ses/by/4.0/.

\section{References}

1. Austin, John. 1993. Mówienie i poznawanie: Rozprawy i wykłady filozoficzne. Warszawa: PWN.

2. Convention for the Protection of Human Rights and Fundamental Freedoms. 1950. Rome.

3. Goetz, Peggy. 2003. The effects of bilingualism on theory of mind development. Bilingualism: Language and Cognition. https://doi.org/10.1017/S1366728903001007.

4. Iwanicka, Anna. 2013. Koncepcje procesów interioryzacji i eksterioryzacji w kulturze. Drohiczyński Przeglad Naukowy. Wielokulturowe Studia Drohiczyńskiego Towarzystwa Naukowego 5: 95-110.

5. Kant, Immanuel. 1998. Critique of pure reason. Cambridge: Cambridge University Press.

6. Kowalczyk, Joanna. 2017. Pragmatyka komunikacji urzad-obywatel. Kraków: Libron.

7. Kowalczyk, Joanna. 2018. Gatunkowa polimorficzność językowa w wyrokach sądów. Stylistyka 26: 135-151.

8. Krótki, Zuzanna. 2014. Eufemistyczne nazwy stosunku seksualnego w historii języka polskieg. In Bogactwo polszczyzny w świetle jej historii, vol. 5, ed. J. Przyklenk, 140-153. Katowice: Wydawnictwo Uniwersytetu Śląskiego.

9. Kwintylian, Marek Fabiusz. 2012. Ksztatcenie mówcy. Księgi VIII 6-XII. Kraków: Księgarnia Akademicka.

10. Limberger, Bernardo, Buchweitz Augusto. 2014. The effects of bilingualism and multilingualism on executive functions. Fórum Linguístico. Florianópolis 11/3. https://doi.org/10.5007/1984-8412. 2014v11n3p261.

11. Maloy, Jason. 2009. Two concepts of trust. The Journal of Politics 71 (2): 492-505.

12. Myers, Marie. 2006. Code-switching in business communication: Stimulating versus impeding relations with intercultural and diverse groups. In eds. M. Boenigk, M., D. Krieger, A. Belliger, and Hug Christoph. Innovative Wirtschaftskommunikation. https://doi.org/10.1007/978-3-8350-9663-9_ 14.

13. Nilep, Chad. 2006. "Code switching" in sociocultural linguistics. Colorado Research in Linguistics 19: $1-22$.

14. Perelman, Chaim. 2020. Imperium retoryki Retoryka i argumentacja. Warszawa: PWN.

15. Petty, Richard, and Caccioppo John. 1986. Communication and persuasion: Central and peripherial routes to attitude change. New York: Springers. 
16. Petty, Richard, and Caccioppo John. 1986. The elaboration likelihood model of persuasion. Advances in Experimental Social Psychology 19: 123-205.

17. SEP-Spade, paul Vincent, panaccio Claude, William of Ockham, ed. In E.N. Zalta. In The Stanford Encyclopedia of Philosophy (Spring 2019 Edition). https://plato.stanford.edu/entries/ockham/.

18. Seuren, Pieter. 2005. Eubulides as a 20th-century semanticist. Language Sciences 27: 75-95.

19. Sherif, Muzafer, and Cantril Hadley. 1947. The psychology of ego-involvements: Social attitudes and identifications. New York: Wiley.

20. Sherif, Carolyn, Sherif Muzafer, and Nebergall Roger. 1965. Attitude and attitude change: The social judgment-involvement approach. Philadelphia: WB Saunders.

21. Siegel, Harvey. 1999. Argument quality and cultural difference. Argumentation. https://doi.org/10. 1023/A:1026466310894.

22. Skrętowicz, Edward. 2013. Funkcja oraz istota ustnych motywów i uzasadnienia wyroku w procesie karnym. Studia Iuridica Lublinensia 19: 275-283.

23. Sczepankowska, Irena. 2004. Język prawny I Rzeczypospolitej w "Zbiorze praw sqdowych" Andrzeja Zamoyskiego. Czesś I: POJĘCIA PRAW. Białystok: Wydawnictwo Uniwersytetu w Białymstoku.

24. Wołodkiewicz, Witold. 2006. Łacińskie paremie prawnicze w polskiej praktyce prawnej, ed. W. Wołodkiewicz. In Regulae iuris Łacińskie inskrypcje na kolumnach Sadu Najwyższego Rzeczypospolitej Polski, 1-12. Warszawa: C.H. Beck.

25. Woźniak, Joanna. 2017. Latinisms in legal texts-A contrastive approach Polish-German. Comparative Legilinguistics 31: 69-88.

26. Zarefsky, David. 2020. Underlying assumptions of examining argumentation rhetorically. Argumentation. https://doi.org/10.1007/s10503-019-09501-2.

\section{Source materials}

27. Portal Orzeczeń Sądów Powszechnych. https://orzeczenia.ms.gov.pl. Accessed 5 March 2021.

28. IIAKa 49/16-Wyrok Sądu Apelacyjnego w Krakowie z dnia 27 kwietnia 2016 roku, sygn. akt IIAKa $49 / 16$.

29. V ACa 906/14 - Wyrok Sądu Apelacyjnego w Gdańsku z dnia 5 marca 2015 roku, sygn. akt V ACa 906/14.

30. I C 1336/16-Wyrok Sądu Rejonowego w Wieliczce z dnia 17 października 2016 roku, sygn. akt I C $1336 / 16$.

31. II AKa 118/14-Wyrok Sądu Apelacyjnego we Wrocławiu z dnia 14 maja 2014 roku, sygn. akt II AKa 118/14.

32. III K 190/18 - Wyrok Sądu Okręgowego we Wrocławiu z dnia 17 stycznia 2019 roku, sygn. akt III K $190 / 18$.

33. II K 550/18 - Wyrok Sądu Rejonowego w Tucholi z dnia 12 kwietnia 2019 roku, sygn. akt II K $550 / 18$.

34. II K 96/15-Wyrok Sądu Okręgowego w Częstochowie z dnia 30 grudnia 2016 roku, sygn. akt II K $96 / 15$.

Publisher's Note Springer Nature remains neutral with regard to jurisdictional claims in published maps and institutional affiliations. 